NORDISK MUSEOLOGI $1993 \cdot 1$, S. 45-59

\title{
DET ARKEOLOGISKE MUSEUM MOMENTER TIL EN KRITIKK
}

\section{Bjørnar Olsen}

\begin{abstract}
Museet utgjør arkeologiens viktigste institusjonelle forbindelse til offentligheten. Folk flest assosierer arkeologi nettopp med museer, med museal praksis. Tilkomsten av en arkeologisk disiplin var da ogsà avhengig av det forhistoriske museets tilkomst. Begge kom til i det tidlige 19. arrbundrets kontekst av sannhetstrang og nostalgi. Eksistensbetingelsene var skapt av bruddet $i$ den europeiske tenkemåte på overgangen mellom det 18. og 19. århundre da, ifolge Michel Foucault, tilkomsten av det moderne episteme muliggjorde tenking omkring organiske prosesser, historisk opprinnelse og evolusjon.
\end{abstract}

I arkeologiske lærebøker og i offisielle manifest hevdes det at museenes samfunnsrolle er å ta vare på - bevare - fortida for kommende generasjoner, og å formidle kunnskap om fortida til de besøkende. I den definisjon av museum som "The International Council of Museum" (ICOM) har laget heter det, noe tvetydig, at "Et museum er en ikke-kommersiell, permanent institusjon som tjener samfunnet og dets utvikling, og som vender seg til allmennheten; samler inn, bevarer, utforsker, formidler og utstiller materiale om mennesket og dets miljø i studiemessig og stimulerende hensikt" (Statens Museumsråd 1986). Likeledes poengteres det ofte at museet skal gi historisk sammenheng og stabilitet, og dermed røtter og identitet til samfunnet (Johansen 1989). Museet i sin arkeologiske utforming skal være et bolverk mot oppbrudd og forvitring $i$ en verden preget av stadig forandring.

Jeg kunne gi flere slike eksempler på offi- sielle ytringer om museets samfunnsmessige funksjon. Men det rekker til å forstå at i det offentlige ordskiftet er det omgitt av en aura av godhet og velvillig sympati. Det ivaretar en veldedig funksjon $\mathrm{i}$ form av å ta vare på fortida og å formidle den til samfunnsborgerne. Museet er således vel ansett, har en status ikke så ulik de humanitære hjelpeorganisasjoner. Kan man tenke seg noe mer prisverdig, uegennyttig og idealistisk? Kan noen være så hjerterå å kritisere denne veldedige virksomhet?

Enkelte kan visst. "Riv museene" skriver Marinetti i "The futurist manifesto" (1965). "Befri Italia for dets professorer, arkeologer, ciceroner, og antikvarer... Museer, gravplasser, ett og samme! Frem med de velsignede pyromaner! Grav nye løp for kanalene og sett museene under vann!" (etter Johansen 1990: 44). I sin tale i forbindelse med ICOM's 9. generalforsamling hevdet Stanislas Adotevi at museet er "forblitt den priviligerte tumleplass for forstøvete beset- 
46 telser av en klasse som fortsatt tror på utvidelse av sin makt" (Gjestrum og Maure 1988). "Begrepet museal", sier Adorno, "har en ubehagelig biklang. Det beskriver gjenstander i ferd med å dø...Museum og mausoleum er forbundet med mer enn en fonetisk assosiasjon" (Adorno 1984: 175). Andre igjen har beskrevet museet, og med direkte referanse til det arkeologiske, som maktinstitusjoner og brikker i det ideologiske statsapparat. Man beskylder det for kommersialisme, at det forkynner monotoni og passivitet, og at det utøver terror mot den besøkendes tanker om fortid (f.eks. Leone 1981, Shanks og Tilley 1987, Olsen 1988, Adolfson 1987, Merriman 1989, Ekeland 1990).

Uten å ta stilling til innholdet $\mathrm{i}$ disse utsagnene viser de at det $\mathrm{i}$ tillegg til det offisielle syn på museets virksomhet også eksisterer et kritisk ordskifte om det museale. Innenfor arkeologien har denne kritiske samtale, som generelt kunne beskrives som en diskurs om fagets og fortidas sosio-politiske rolle i nåtida, kommet til å prege den teoretiske debatten det siste 10-året (Hodder 1984, Shanks og Tilley 1987, Olsen 1987). Med spesiell referanse til museet kan man kanskje si det slik at debatten blant annet har dreid seg om følgende: Museene presenterer fortida, men er selv en del av nåtida og dens økonomiske og sosio-politiske praksiser. Istedenfor å akseptere påstanden om at museenes oppgave er å ta vare på og formidle fortida, har man istedet spurt seg om i hvor stor grad det er nåtida og dens sosio-kulturelle form museene bevarer. Den amerikanske arkeologen Mark Leone har formulert dette poenget slik (1982: 750): "ettersom vi er medlemmer av et kapitalistisk samfunn med sin egen ideologi, og ettersom vi vet at en måte ideologi opererer på er å gjøre nåtida uungåelig gjennom å få fortida til å fremstå som en naturlig forutsetning for moderne forhold, i hvilken grad skaper da arkeologien fortida i sitt bilde".

Med utgangspunkt i denne debatten skal jeg i denne artikkelen reise et kritisk søkelys mot det arkeologiske museum og dets formidlingspraksis. En av mine påstander er som følger: de arkeologiske utstillinger, slik jeg kjenner dem fra Skandinavia, Europa og USA, fungerer i betydelig grad til å gi ideologisk legitimitet til vår moderne, vestlige livsform. Dette skjer ved at de fjerner det historiske og partikulære ved såvel fortid som nåtid. Historisiteten til både fortida og nåtida er visket bort. Alternativene til, og det bisarre i, vår egen livsverden er fortiet $\mathrm{i}$ den moderne universalistiske meta-fortelling som museene formidler.

Jeg vil også hevde at dette mye er et resultat av at museene og de som lager utstillinger i det vesentlige ser sin oppgave som et spørsmål om kommunikasjon. Hvordan skal budskapet formidles på en best mulig, og mest overbevisende, måte? Vektleggingen av retorikken, overtalelsekunsten, har gått på bekostning av en diskusjon om innhold. Det vesentlige problem om produksjon av fortid er tilslørt ved å gjøre det om til et kommunikasjons-problem.

På tross av museene i sin formidling av fortida kunne sies å fremstå med en retorisk form og et ideologisk innhold som styrker hegemoniet til de herskende interesser i nåtida, så vil jeg selvsagt ikke påstå at dette er et resultat av bevisste manipulasjoner. Jeg vil heller hevde at den kanskje viktigste drivkraften er de mulighetsbetingelser som samtidas kulturindustri gir museet, hvor kampen om konsumentene, publikum, fremtvinger en slik orientering. 
REALISMEN OG DET MODERNE MUSEET

Utgangspunktet for dette innlegget er det moderne, pedagogiske museet slik vi kjenner det fra den vestlige verden. I løpet av de 170 år som er gått siden historien valgte seg C. J. Thomsen til å ordne det tidligere "kunstkammeret" i København til et disiplinert arkeologisk museum har museenes formidling av arkeologi endret seg betydelig. På tross av at mange trekk henger igjen, noen steder mer enn andre, har det især innenfor de siste 20 årene foregått en markert endring av museenes presentasjon av den fjerne fortid. I korthet kan denne endringen best beskrives som en overgang fra en objektfiksert presentasjonsform hvor typologi og kronologi var de viktigste struktureringselementene, til en kontekstuell og "pedagogisk" utrykksform hvor kommunikasjon og identifisering spiller en stadig mer sentral rolle. Ikke minst her i Skandinavia er denne forandring $\mathrm{i}$ den museale praksis påtagelig. Borte er de endeløse rekker av flintøkser, sverd og dolker, tilbake - hevdes det - er det forhistoriske mennesket, ja forhistorien selv (Olsen 1988).

Kommunikasjon og gjenkjennelse er noen av stikkordene for det nye museum. Det stadig mer sentrale budskapet har blitt: hvordan formidle budskapet bedre? Hvordan (re-)presentere fortida på en mest mulig realistisk måte? De tradisjonelle utstillingene maktet denne oppgaven dårlig. De var kjedelige og fremmedgjørende. Gjenstandene ble presentert løsrevet fra sin naturlige kontekst, innskrevet i typologiske rekker fremmed for deres opprinnelige bruk. I ei tid da kino, sport, TV og ukeblader på en langt mer fengende måte tildro seg publikums oppmerksomhet var det åpenbart at de tradisjonelle museale presentasjonsformene bokstavelig talt var akterutseilt. Massekulturen og det nye mediabildet skapte konsumenter med helt andre forventninger til underholdning og informasjon enn hva museene var i stand til å tilfredsstille. Uansett hvordan man ser på det, 60 rustne jernsverd på rekke kan knapt kalles god underholdning.

Noe måtte gjøres. Det arkeologiske museum måtte finne sin plass som moderne massemedium. Svaret ga seg i form av nye utstillingsteknikker og progressiv undervisningsteori. En opplevelse av fortid måtte bringes inn i museene, en aura av fortidig autensitet måtte gjenskapes. Den enkleste måten å oppnå dette på var å sette gjenstandene i kontekst, innskrive dem i sin opprinnelige sammenheng. Dette kunne gjøres ved for eksempel å rekonstruere et boplassmiljø fra steinalderen. Rundt et utbrent ildsted plasserte man noe steinavfall og redskap, samt litt skinn og noen byttedyr. Dette ble igjen plassert $\mathrm{i}$ en miljømessig ramme: Noen planter, utstoppede dyr, og en fotografert eller malt horisont. I mer avanserte versjoner kan dette bildet utfylles ved hjelp av audio-visuelle hjelpemidler som endrer lyssettinger, imiterer dag og natt, og lager lyder fra dyr og vannfall. Den besøkende skal få en opplevelse av å tre inn og være tilstede i fortida, erfare autensitet.

Denne effekten kan forsterkes gjennom "forsøk med fortiden", hvor den besøkende selv kan få prøve seg på arbeidsoperasjoner med tiltenkt fortidig "ekthet". En rendyrking av denne genren skjer gjennom oppbygging av eksperimentelle sentra som viser hvordan redskapene ble laget og brukt. Her finner man også riktige rekonstruksjoner av hus og båter. Her kan vi besøke fortiden, vi 
48 kan reise gjennom årtusener og tilbringe en $\mathrm{dag}$, en weekend eller en uke $\mathrm{i}$ steinalderlandsby, leve på steinaldervis. Vi kan selv oppleve hvordan det "egentlig var" å være steinaldermenneske på Vuollerim i Norrland. Eller på Lejre, Sjælland, bare en halv time med tog fra København. Eller du kan dra til York og vikingbyen Jorvik, sette deg på et annet tog som i løpet av sekunder frakter deg gjennom århundrene til en visstnok autentisk gate i Jorvik. Autensiteten av denne rekonstruksjonen garanteres av "Jorvik Times", som hevder at dersom vikingene selv skulle ha returnert ville de ha følt seg helt hjemme (Shanks og Tilley 1987: 86). Her kan vi oppleve håndverksbodene, luktene og lydene.

Gjennom disse rekonstruksjoner skal den besøkende rå en opplevelse av å være til stede $\mathrm{i}$ fortida, få oppleve en virkelighetseffekt. Dette er historia, ikke en fremstilling av den. Denne trangen til det virkelige er på mange vis et typisk trekk ved kulturproduksjonen i det moderne samfunn, eksemplifisert ved fotografiet, dokumentarlitteraturen, den realistiske novellen og ikke minst, opplevelsesturismen.

Innenfor litteraturen er realismen en stilart som kjennetegnes ved at den utgir seg for å være en ikke-symboliserende, gjennomsiktig skriveform som på en helt passiv måte representerer virkeligheten. Undertrykkelsen av forfatterstemmen er sentral i denne genren, derved skapes hva den franske tegnforskeren Roland Barthes (se Olsen 1990) kalte en "referensiell illusjon" (Barthes 1986: 132): det er virkeligheten selv som forteller. Realismen hevder kommunikasjon som språkets og tekstens hovedfunksjon. Den skulle på en klarest mulig måte avspeile virkeligheten, kommunisere eller omsette allerede gitte og utvety- dige meninger. Som Barthes fremhever, "den organiserer en verden uten motsetninger fordi den er uten dybde, en vid åpen verden som velter seg i sin egen tydelighet, den etablerer en lykksalig klarhet: ting synes å få mening av seg selv" (Barthes 1973: 143).

Jeg har tidligere brukt begrepet formidlings-fetisjisme om denne retoriske formidling av ekthet og realisme i de arkeologiske museer (Olsen 1988). Dette fordi det avgjørende problem om produksjon av fortid er maskert og gjort om til et kommunikasjons- eller omsetningsproblem. Som kjent brukte Marx begrepet "vare-fetisjisme" for å beskrive et særlig fenomen ved det kapitalistiske samfunns ideologi. Denne postulerte at varenes sirkulasjon på markedes var deres egentlige og eneste eksistens, det som ga dem verdi. Gjennom dette ble produsent og produksjon av varer, deres sosiale verdiskapning, skjult.

På tilsvarende vis er produksjon av fortid og de konflikter og ulike interesser som er involvert $\mathrm{i}$ denne, fremmedgjort og isolert fra $\sin$ museale presentasjon som vare på kulturmarkedet. Produktet fremstår uten produsent. Som i den realistiske romanen er forfatteren usynliggjort. På museet fremstår fortidas presentasjon som gudegitt, et produkt uten signatur, nennsomt pakket for passivt konsum. Vi ser scenen, men ingen regissør; tekstene, men ingen forfatter (Olsen 1988, Ekeland 1990).

Museets fokusering på presentasjonsteknikker tilslører problemene forbundet med produksjon av fortid. Den fremstiller en idyllisk konsensus om fortida, at det eksisterer et gitt sett av kunnskap, hvor problemet bare består i å overføre denne kunnskap fra A til B, fra "viter" til "ikke-viter". Haken ved det hele er selvsagt at det ikke 
eksisterer noen enighet om fortida i dagens arkeologi. Bak betongveggene bare noen meter unna utstillingens idylliserende konsensus foregår det diskusjoner, krangler og maktkamp på museenes forskningsavdelinger. Det er en kløft, en avgrunn, mellom formidling og forskning. Stikk i strid med oppfatningen av fortiden som et avsluttet prosjekt som enkelt, om enn møysommelig, lar seg rekonstruere finnes det en lang rekke rivaliserende oppfatninger om hvordan den skal produseres. De spørsmål vi stiller, og de svar vi er villige til å akseptere, er avhengig av såvel teoretisk ståsted som av kulturelle og politiske verdier i samtida. Det eksisterer ingen gitt monolittisk fortid som ganske enkelt kan avdekkes. Istedet finnes det mange og konkurrerende fortider avhengig av ulike sosiale og kulturelle verdier både i fortid og nåtid.

Museet - også på grunn av sin seine utskiftningstakt av basisutstillinger - bidrar til å maskere disse konfliktene. Det fremstiller en monoton og uproblematisk historie, som søkes kommunisert med de mest effektfulle overtalelsesteknikker. Derfor begrepet formidlings-fetisjisme.

Den videre framstilling skal dreie seg om en analyse av museets mytologi, og om hvordan denne formidles, d.v.s. en analyse av museets innhold og form.

\section{MUSEETS MYTOLOGI}

I sin bok Mytologier (1973) gjør Roland Barthes en analyse av vår tids kultur-produkter som reklame, sport, museer, moter, mat, etc.. Han viser her hvordan det moderne samfunn anvender myter for å naturalisere sosialt og kulturelt avhengige meninger, og dermed bevarer eksisterende maktrelasjoner. Myten universaliserer ver- den som umiddelbart selvfølgelig og motsetningsløs, hvor igjennom den dominerende orden rasjonaliseres som naturlig orden, som den eneste mulige og fornuftige måte å organisere verden på. Dette budskapet kommuniseres indirekte og forkledd, som en ideologisk stemme bak og over den direkte mening. Mytens effekt er å få den tilfeldige relasjon mellom uttrykket, det være seg ord, bilder, objekter eller handlinger, og det ideologiske innholdet de tillegges, til å fremstå som en naturlig enhet, noe selvsagt utenfor menneskelig fortolkning. Den får ting til å gå uten å si det direkte, gir ting og meninger "en naturlig og evig berettigelse..en klarhet som ikke tar form av en forklaring, men av å slå fast fakta" (Barthes 1973: 143). Meningen er altså ikke produsert, den er gitt, iboende i tingen, ordet eller handlingen.

Hva $\mathrm{i}$ all verden er da mytologisk eller ideologisk ved noe så uskyldig som ei arkeologisk utstilling? For folk flest er det ikke noe ideologisk ved arkeologien i det hele tatt. Dette gjør den selvsagt til et perfekt sted for mytologi. Arkeologiens mytologiske virksomhet består $\mathrm{i}$ å frata fortiden sin historisitet. Effekten er at det historiske og tilfeldige fjernes fra verdier og adferd $\mathrm{i}$ vår egen samtid. Ved å overføre dagens verdier, inntrykk og adferd på fortida, blir deres nåtidige eksistens og lokalisering naturalisert og universalisert. Vi kan så peke på fortida og si: se, det har jo alltid vært slik!

På det arkeologiske museum blir vi ofte presentert for en fortid som virker umiddelbart familiær for oss. I de nye pedagogiske utstillingene møter vi velkjente størrelser som teknologi, økonomi, bosetning og religion, bare med litt forskjellig innhold. Bare vi hadde mestret endel teknikker hadde vi 
50 faktisk godt kunne levd i steinalderen. Enkelte steder får man da også tilbud om å leve steinalderliv for en uke. Vi lærer om teknologi, hvordan de lagde sine steinredskap, hvordan de fanget elg eller dyrket korn. "Gjenkjennelsesromantikken" (Hansen 1979) får fritt utløp. Det hele virker håndgripelig og nært. I sin temmete utgave virker steinaldermennesket umiddelbart forståelig. Bare vi skraper vekk en del ytre forskjeller står vi tilbake med en universell menneskelig natur.

Mine innsigelser mot disse utstillingene er at de fjerner historisiteten i fortida. At de fratar oss fremmedheten og polariteten ved den. Forskjellene er redusert til et minimum, til det som går å si i vår egen samtid, det som holder et anstendig nivå for en familieforestilling. Vi får vite mye om hvordan flintøkser slipes, men lite om barnedrap og kannibalisme. Mye om keramikkproduksjon, men lite om ritualer og sex.

Et eksempel hentet fra en artikkel av den amerikanske arkeologen Mark Leone kan illustrere litt av poenget (1981). Artikkelen omhandler friluftsmuseet Shakertown på Pleasent Hill, Kentucky, USA. Museet er organisert som en landsby bestående av to dusin originale bygninger. Stedet er befolket av aktører i original bekledning, og disse beretter om stedet og dets opprinnelige samfunn. I tillegg blir informasjon formidlet gjennom brosjyrer og guidebøker.

Shakertown er et museum over shakerne, et religiøst samfunn grunnlagt av engelske settlere ledet av Mother Ann Lee på slutten av 1700-tallet. Shakerne bodde i egne samfunn, og fikk sitt navn p.g.a. ekstatiske danser som de henga seg til på sine gudstjenester. Shakerne praktiserte sølibat, nye samfunnsmedlemmer ble rekruttert gjennom omvendelse. De var organisert i stor- familier, men kvinner og menn levde strengt adskilte, kunne ikke berøre hverandre og hadde kjønnsspesifikke arbeidsoppgaver. De praktiserte en unik form for agrarindustrialisme bestående av en omfattende produksjon av håndverksprodukter, mat og medisin, basert på råvarer fra eget jordbruk.

Shakerismen lignet på en del utopiske sosialistiske samfunn. Som disse reagerte den mot trekk ved den fremvoksende industrikapitalismen som fabrikkarbeid, oppløsningen av storfamilien og økende vektlegging av individuelle sosiale relasjoner. Shaker-samfunnet var også en reaksjon mot effektivitet som målestokk for adferd, og mot rasjonaliteten og de avtagende emosjonelle uttrykk i de etablerte kirkesamfunnene.

På friluftsmuseet på Pleasant Hill blir vi presentert for en spesiell fortolkning av Shakernes kultur. Vi får ganske riktig vite om sølibatet, dansene og at de trodde på noen sære ting, men det som vektlegges er hvor praktiske, oppfinnsomme og arbeidsomme de var. Deres dyktighet i handel og håndverk blir fremhevet, alt fra teppeveving til medisinproduksjon blir nitidig beskrevet. Som en ideologisk rettesnor får vi vite at de produserte og eksportere mye mer enn de selv konsumerte og importerte, at de utviklet arbeidsbesparende teknologi, og følgelig hadde et stort overskudd av sin produksjon. Man formidler ikke at denne profitten ble kommunalt fordelt, eller at sammenbruddet for Shakernes spesielle versjon av agrar-industrialismen skyldes at den ble oppslukt av den moderne kapitalismen.

I sin analyse av denne presentasjonen av Shakernes samfunn skriver Leone, "å fremstille shaker-kulturen som effektiv, profittabel og logisk...er å gjøre kultur til et pro- 
dukt av funksjon, adferd til et produkt av effektivitet, og tanken til et produkt av materiell nødvendighet. Dette er selvsagt amerikansk tenking, ikke hvordan alle alltid har tenkt, og trolig ikke hvordan shakerne tenkte" (1981: 305). Leone hevder at den museale presentasjonen av det sterkt religiøse Shaker-samfunnet er preget og styrt av verdier fra nåtidig amerikansk kapitalisme. Effektivitet, kalkulerende rasjonalitet, industri, eksport og profitt utgjør de temaer museumsutstillingen er organisert etter. Leone hevder at det religiøse shakersamfunnet var totalt forskjellig fra hans eget, samtidige USA. De var totalt forskjellig fra oss. De levde et liv i enkelthet og forsakelse. De arbeidet ikke for profitt, men for å unngå synd. De hadde ingen økono$\mathrm{mi}$, bare et elaborert system av botsøvelser (Leone 1981: 312).

Museet på Pleasant Hill misrepresenter imidlertid Shakernes kultur som instrumentell, praktisk fornuft. Der igjennom bidrar det til å universalisere denne fornuften, og å fjerne dens historiske og kulturelle lokalisering. Samtidig skjuler museet shakernes samfunn for oss, og muligheten for at deres liv kunne fremstå som et alternativ eller en kritisk kommentar til vårt eget.

Shakernes samfunn var trolig uendelig mye nærmere vår egen livsverden enn steinaldermennesket i Alta, på Bjurselet eller ved Varangerfjorden. Likevel ser vi også hvordan disse i sin museale (re)presentasjon legges i fornuftkjedens lenker, slik at historien fortoner seg som en "uendelig repetisjon av det samme" (Foucault 1977).

Selv vår estetiske smak fjernes fra sitt ståsted, den borgerlige estetikk universaliseres. Det umiddelbare inntrykk den besøkende făr ved et besøk til Shakertown-museet er at stedet er svært vakkert, nesten perfekt
(Leone 1981: 301). Så heter det da også Pleasant Hill. Ingenting behøves repareres, rakes eller males, intet søppel. Således fyller det et av de 7 kriteriene Burcaw i sin "Introduction to Museum Work", setter for ei god utstilling: "it must look good". Begrunnelsen for dette, heter det her, er at "a dirty, crudely made, tasteless exhibit will repell the visitor" (Burcaw 1975: 118).

En skitten, vulgær og smakløs utstilling; hvilken og hvem sin smak kunne man spørre. Dette forhold at fortiden skal uttrykke det vakre, det reine og det behagelige kan bli sett som bidrag til definering av den legitime kultur i samtiden, der smaken først og fremst klassifiserer den som har foretatt klassifiseringen. Denne gode smak sublimerer og stiliserer det som kjennetegner det "anstendige menneske", i motsetning til folkets larmende og skitne hedonisme. Estetikken kan sees som en sosial formidling, den representerer ikke noe ahistorisk eller apolitisk rom. Følgelig kan man stille spørsmål med hvem sitt skjønnhets- og nytelsesideal den representerer (Bourdieu 1984, Ekeland 1990: 86).

Estetikken har en sentral plass i det arkeologiske museum. Det er de vakre, hele og karakteristiske funn som presenteres. Ingen av de sundslåtte, forrustete artefakter som magasinene flyter over av blir ansett presentable. Selv i det nye, pedagogiske museum, finnes det fremdeles plass til det unike funn, gjerne fra jernalderen eller vikingtid, til hva Gundula Adolfson (1987) har kalt "artefaktfiksering". Dette er nok en form for formidlings-fetisjisme, idet gjenstanden løsrives fra enhver sosial og historisk kontekst, og gjøres om til et symbol på universell estetisme, et objekt for sorgløs nytelse.

Selv ved presentasjon av mindre unike funn blir estetikken en vesentlig del av for- 
52 midlingen. For å sikre seg at den besøkende ikke gjør seg opp feil mening, må denne skjønnheten ofte poengteres i den akkompangnerende tekst. Således bemerker Johansen det eiendommelige $\mathrm{i}$ at det på vignetten til en monter for båtøkser på Stavanger Museum ikke bare står å lese: "Stridsøkser, yngre steinalder", men også "vakkert utformet og fint slipt" (Johansen 1991: 60). Denne gjenstands-fetisjismen frarøver tingen sin historie. Som Barthes skriver (1973: 151), "alt som står igjen til oss å gjøre er å glede oss over dette skjønne objekt uten å undre oss over hvor det kom fra. Eller til og med bedre: det kan bare komme fra evigheten, siden tidenes morgen har det blitt laget for det borgelige mennesket".

Hvordan kommuniseres så dette budskapet, hvilke retoriske teknikker tas i bruk?

\section{MUSEETS RETORISKE TEKNIKKER}

Arkeologisk praksis kan beskrives som en de-konstruksjon av et objekt, fortid eller materiell kultur, for så å lage en rekonstruksjon ved hjelp av de bøker vi skriver eller de museale utstillinger vi lager. I denne antatte kopi kan fortida, ved hjelp av fine funn som passer inn $i$ vår oppfatning av den, fremstå som sikker, klar, gitt, "der" på et vis (Olsen 1990: 195). Museet bidrar med andre ord til å kreere fortida, skape dens klarhet og logikk, fjernt fra det fragmentariske kaos av uforståelige strukturer, forsvunne avslag, misforstått strategrafi, bakrus og regnvær, den ble gravd frem i.

På museet brukes materielle objekter til å kreere dette simulacrum, og selv om man her skjønnsomt velger ut de riktige funn, de som passer inn, har man et likevel et problem: I langt større grad enn ord, er materielle objekter polysemiske, d.v.s. flertydige. Under deres uttrykk ligger en flytende kjede av betydninger. Denne flertydigheten skaper usikkerhet i en "sivilisasjon som begjærer tegn, men som liker at de er sikre" (Barthes 1977: 29). Fortiden kan bli kaotisk og ute av kontroll, forhistoriske monument og gjenstander kan bety hva som helst. Som Eugenio Donato skriver i "The Museum's furnace" (1979), "Museumsutstillingene understøttes av den fiksjon, at tingene på en eller annen måte skulle utgjøre et sammenhengende univers av representasjoner skulle fiksjonen gå i oppløsning er det ikke annet igjen av museet enn krimskrams" (etter Johansen 1991: 65).

Denne mangel på kontroll over objektenes betydning, fremtvinger teknikker som kanaliserer fortolkningen, som knytter uttrykk og innhold sammen, slik at en riktig forståelse av objektet fremkommer. Derfor, skriver Roland Barthes (1977: 29), er det $i$ et hvert samfunn utviklet ulike teknikker med det formål å fiksere og binde den flytende rekke av betydninger for på en slik måte å motvirke terroren fra de usikre tegn: den språklige beskjed er en av disse teknikkene. Og vi ser at overalt, også i det arkeologiske museum, brukes tekster eller språklige beskjeder som det viktigste hjelpemiddel til a binde betydninger. Denne intervensjon av en tekstuell beskjed har, som Barthes sier det, til oppgave å "dirigere leseren gjennom objektets meninger, tvinge henne til å til å unngå noen og motta andre, ved hjelp av en ofte listig overføring, fjernstyrer den henne mot en mening bestemt på forhånd" (Barthes 1977: 40). Teksten er retorisk, den overtaler leseren av det materielle objekt til å akseptere en forutfattet mening, en mening tilsynelatende 
ikke skapt av noen, men som ved tilforlatelige knep synes å være iboende i objektet selv.

La oss se litt på hvordan dette fungerer i praksis. La oss se på en arkeologisk utstilling. Eksemplet er hentet fra Moesgård Museum i Århus, og jeg har brukt det flere ganger tidligere (til det kjedsommelige vil noen hevde) (Olsen 1987, 1988, u.å.). Dette museet huser en av Skandinavias mest moderne steinalderutstillinger, ihvertfall var den det da jeg siste gang besøkte Moesgaard i 1985. Vi skal se på hvordan presentasjonen av en monter med tidligneolittiske artefakter, bl.a. økser og keramikk, kan makte å formidle et spesielt ideologisk budskap. Objektene i seg selv har få begrensninger $i$ de meninger som kan tillegges dem, og de kan gi oss mange assosiasjoner. Flintøkser, for eksempel, kan gi assosiasjoner til felling av trær, til kamp og drap, til lederskap og makt, kjønn eller etnisk tilhørighet, alt dette er plausible arkeologiske tolkninger. Den besøkende på sin side kan kanskje få den største opplevelsen ved at han gjenkjenner flintøksen fra sin bestefars arbeidsværelse, brukt som bokstøtte.

På vårt museum, som ikke er atypisk eller spesielt, forsøker man å dirigere den besøkendes tolkning av disse gjenstandene gjennom visse teknikker av overtalelse. Denne retorikken er bygd opp gjennom flere nivåer, som en kjede av supplementer, ment å oppfattes som "tilleggsinformasjon", men som også har den effekt at den reduserer antallet tolkningsmuligheter, og binder visse meninger til objektene.

Kjeden starter altså med endel utvalgte tidlig-neolittiske objekter, som i seg selv er åpne for mange fortolkninger. Den første alvorlige meningsreduksjon inntrer ved at gjenstandene gjennom deres montage settes i sammenheng med fenomen det ikke er umiddelbart gitt at de er naturlig forbundet med, i dette tilfelle jordbruk. For ytterligere å redusere og kontrollere mening introduseres så nytt ledd i den retorisk kjeden: de materielle tegn invaderes av en språklig beskjed, et hvitt skilt med tekst. Objektenes opprinnelige pluralitet kveles nå $i$ et konkret og overbevisende budskap som lader dem med en forutbestemt mening og en moral. Og så har det magiske skjedd, en helt ny betydning som man ikke kunne lese ut av objektene selv, presenteres uskyldig, ikke som en forklaring, men som "a statement of fact". For på det akkompagnerende skilt står det å lese: "Jordbruk gjorde det mulig for folk å begynne å bo fast".

Vi reagerer knapt nok. Mytens ideologiske innhold er godt skjult bak et velvalgt uttrykk, lett absorberbart, uskyldig - sier bare hva som sies. Kanskje kan det avdekkes ved å spørre om hva som hadde skjedd om vi hadde erstattet utsagnet "gjorde det mulig" med det mindre demokratiske uttrykket "tvang". Om det i stedet hadde stått at jordbruket tvang folk til å bli bofaste, tvang dem til å oppgi et liv i frihet, så ville selvsagt meningsinnholdet vært et helt annet. Og her ser vi det igjen, vi foretrekker det familiære, det som naturaliserer vår egen neolittiske livsform og ideologi, som fjerner historisiteten både ved det forgangne og nuet. Beskjeden er klar: de var som oss, takket være jordbruket ble de tillatt å bo fast som oss, og leve det gode liv som siviliserte mennesker, slik vi gjør. Effekten er terapeutisk, fortida god å tenke.

Hvorfor er det så viktig at meningen holdes under kontroll? Aner vi noe av sammenhengen når Burcaw i sin "Introduction to museum work" (1975), nærmest beskri- 
54 ver museets funksjon på linje med et industriforetak med klare produksjonsmål. Det heter her i kapitlet om permanente utstillinger at "sluttproduktet er ikke samlingene, museene, utstillingene, ja selv det at den besøkende ser utstillingene. Dette er bare midler. Sluttproduktet er de endringer som har funnet sted i hodet på folk. Det er dette museene er til for, og målestokken for et museums suksess er hvor godt summen av disse mentale endringene er i samsvar med, eller tjener, museets målsetninger" (1975: 120). Og, legges det til, "på helt samme vis som en maskins effektivitet kan måles gjennom den arbeidsmengde den utfører for den energimengde som skal til for å operere den, kan vi beregne museets effektivitet ved å sammenligne hva vi oppnår mot det vi forbruker" (1975: 120).

\section{FRA OPPLYSNING TIL KULTUR- INDUSTRI}

Kanskje er museene en industri, ihvertfall inngår de $\mathrm{i}$ nåtidige sammenhenger som den ikke kan frigjøre seg fra. Vi lever i en post-industriell tidsalder, men én industri har bare vokst og vokst: kulturindustrien. Det ble hevdet innledningsvis at museet også skulle underholde. Det kan synes som om drivkraften i mye av den utvikling som er skissert ovenfor i stor grad er et resultat av kommersialismen. Av museets tilpassing til markedet. Gjennom generelle sosiale, økonomiske og politiske prosesser blir fortida kommodifisert, gjort om til en vare på det kapitalistiske markedet. Museet, det arkeologiske inkludert, fremstår idag primært som et fritidstilbud, et alternativ til film, sirkus, teater eller fotballkampen på søndag. Og konkurrent. Ingen kan la være å ta hensyn til besøkstallene. Derav følger markedsføring, tabloidisering og yorkisering, vikingland og steinalderland. Museet har blitt en intergrert del av kulturindustrien.

Samfunnkritisk forskning har brukt begrepet kulturindustri til å beskrive et særlig trekk ved den moderne ideologi- eller myte-produksjon (Held 1980). Fra midten av dette århundret har de herskende ideer stadig mer effektfullt blitt kommunisert gjennom massekulturen, radio, TV, film, sport og reklame. Via denne foregår det en ekstrem sosialisering av individene gjennom styring og kontroll av folks fritid. Kulturen blir gjort om til en industri. Profittmotivet overføres til kulturelle former, flere og flere artistiske produkt gjøres om til vareslag. Alt kan kjøpes. Kulturindustrien beskriver en sfære karakteristisk for fremmedgjøringen av mennesket i det moderne, rasjonelle samfunn, hvor kultur kunst - ikke lenger er en inkorporert del av livet, noe man lever i, men noe man konsumerer fremførelsen av. Begrepet kulturindustri refererer til standardiseringen av de kulturelle enhetene, og til rasjonalisering av tilbud og etterspørsel (Adorno og Horkheimer 1979).

Den sosiale effekt av kulturindustrien er flukt og distraksjon. Flukt fra en hverdag preget av håpløshet, depresjon, kjedsomhet og konflikter. Den gir underholdning, avslapping fra krav og oppgaver. For at dette skal virke må kulturindustrien innrette seg mot å produsere produkter som folk vil ha, men som må kunne mottas passivt, avslappet og ukritisk. Det må være ferdigtygd. Hvert produkt er forsøkt fremstilt med et individuelt preg, men bygger på velkjente elementer. I de fleste filmer kan vi forutsi slutten, hvem vil vinne, hvem vil tape. En pop-slagers struktur kjenner vi etter bare noen fà takter. Resultatet er stan- 
dardisering, selve stikkordet for kulturindustrien. Ja, selv responsen, mottakelsen standardiseres. I TV-komediene er latteren spilt inn på forhånd og avspilles på de "rette" stedene. Kommentarer legges hele tiden på i radio- og TV-programmer i tilfelle man skulle være i tvil om hva man skulle mene. Rammer og modeller for fortolkning omsettes samtidig med produktet (Held 1980).

På mange vis tilsvarer de arkeologiske utstillinger, og især i sin nye, pedagogiske utgave, kulturindustriens norm om passivt konsum. Produktet må ikke provosere, men kunne mottas passivt og ukritisk, fylle et behov skapt av de samme som fyller det (j.fr. Burcaws kriterie for en vellykket formidling). Gjenstandene og fortida fremstår i all sin prakt, frembydt i silkemyk innpakning. Gjennom tekstualisering og audiovisuelle effekter sikrer man seg at også responsen standardiseres. Det vil si, man serverer ikke bare produktet, men også hvordan man skal fortolke det. Ved enhver større arkeologisk lokalitet i USA idag er det symptomatisk nok dukket opp ikke museer, men såkalte "interpretation centers" som sikrer riktig fortolkning (Hodder 1991: 13-14). I filmindustrien i USA arrangerer man s.k. "pre-views" for nye filmer, for å sjekke deres kommersielle slagkraft. Med tilsvarende formål har det vært utført studier av de besøkendes adferd i museer, hvilken utstilling blir sett mest på og lengst. På dette vis finner man ut hva som går, hva som fenger interesse, hva som drar publikum. Også museets mål blir å produsere varer som er profittable og konsumvennlige. Resultatet er ideologisk, om enn ikke som resultat av bevisste manipuleringer.
EN ALTERNATIV MUSEAL PRAKSIS

Jeg skal avslutte dette arbeidet med noen ideer til en alternativ museal praksis, og antyde endel virkemidler som kanskje kan bringe den arkeologiske formidlingen vekk fra sin nåværende såpeopera-utgave av fortiden.

En av de tingene vi etter min mening må gripe fatt $\mathrm{i}$ er illusjonen av ekthet, av anonym natur, som dagen presentasjonsformer har reindyrket. Museene må synliggjøre produksjonen og produsentene av fortida. $\mathrm{Vi}$ må vise at utstillingene er produserte av levende og feilbare mennesker, og med bestemte hensikter. Vi må, som Ekeland har fremholdt (1990: 106), synliggjøre også spillet i kulissene.

Kanskje kan vi da hente inspirasjon fra andre kulturer og alternative presentasjonsformer. I det japanske banraku-teatret, et slags dukketeater, styres ikke dukkene av usynlige tråder, men av tre menn som fremtrer utildekte på scenen. Til forskjell fra vår egen kultur, skjules ikke levendegjøringen av dukkene, hele prosessen synliggjøres. Banraku tillater at spillet blir sett, og uttrykker dermed både kunsten og produksjonen (Barthes 1977: 170ff). Tilsvarende gjelder for Brechts åpne teater. Her ligger mye av ideen at man skal bryte ned rutiniserte handlingsmønster og forventninger. Illusjonen av virkelighet brytes i stykker, f.eks. ved at skuespillerne går av scenen og blander seg med publikum. Handlingen avbrytes av sang, ikke for å skape stemning, men for å ødelegge den. Når handlingen i forestillingen begynner å bli konvensjonell, er det på tide å gjøre noe. Man må vekke tilskueren, bryte rammen for det forventede, gjøre henne klar i hodet igjen (Ekeland 1990: 109, Liestøl 1988). 
56 I den arkeologiske utstillingen kan dette gjøres på mange vis. For eksempel kan deler av den formelle orden i utstillingen nedbrytes. I visse tilfeller kan det være på sin plass å ta steinøksene ut av sin forventede ramme, sette dem inn i en ny kontekst sammen med moderne materiell kultur, gjøre dem til latter. Vitsen er ikke å underholde eller estetikk, men å vekke den besøkende opp, få han til å stille spørsmål ved det han ser, til å reflektere over fortid og nåtid.

For å synliggjøre produksjonen av fortida kan et annet virkemiddel være å la utstillingsarbeidet foregå som en mer eller mindre konstant prosess (for dermed å signalisere fortidens uferdighet og kreative dimensjon), og for åpen scene og $\mathrm{i}$ dialog med publikum. Normalt stenger man av utstillingslokalene når en ny utstilling lages. Publikum møter et skilt som sier at bak disse forhengene lages ei ny utstilling som forventes åpnet høsten 1992. Man hører kanskje hamring og saging. Hvorfor ikke la publikum overvære denne produksjonen, endog dras inn i en dialog om hva man gjør og hvorfor man gjør det akkurat slik?

Hensikten med slike og andre tiltak er å synliggjøre produksjonen av fortid, vise den som en aktiv prosess $i$ nåtida. Dette innebærer blant annet å vise publikum endringene, historisiteten, i synet på fortida selv, vise hvorfor det endres og hva det endres i forhold til (Shanks og Tilley 1987: 94 99). I større grad enn hva tilfellet er nå må utstillingene også åpne for flere og konkurrerende syn på fortida, vise pluraliteten $\mathrm{i}$ fortolkningsmulighetene, og oppfordre til kritisk observasjon og deltagelse.

Men, fremfor alt, må museet få frem historisiteten og forskjelligheten ved fortida. Unngå at historien fortoner seg som en uendelig repetisjon av det samme. Den danske forfatteren Martin A. Hansen skriver godt om dette i sin novelle. "Jeg tror", skriver han," det ved dannelsen af en historieopfattelse, der er både redelig og levende, er temmelig viktigt, at der er dialog og polaritet i den, at man gerne vil høre, hvad de gamle kunne tænke sig at sige om oss" (1979: 26). Dermed muliggjør man også at den kan stå frem som en kommentar til vår egen tid som igjen mister sin universelle selvsagthet (Hodder 1990: 15). Vi må vise at det er uendelig mange ting ved fortida som ikke lar seg forklare med vår instrumentelle fornuft, trekk som virker bisarre, ekle og i konflikt med våre egne etiske normer. Det må tilføyes: å presentere fortidas historisitet er ikke å skrive en moralsk historie om fortida som god eller ond, men som forskjellig. Som himlende anderledes enn vår egen tid.

Og hvorfor ikke bruke museet selv som eksempel, vise hvor eksotisk det er. Som mange av de kulturelle manifestasjoner vesten har frembrakt tar vi idag det arkeologiske eller historiske museum for gitt, som et naturalisert fenomen utenfor tid og rom. I de disiplinerte museenes forløpere, raritetskabinettene, "wunderkamrene", finner vi manifistert en måte å organisere verden på som viser at bare for noen få århundrer siden var den europeiske tenkemåte radikalt anderledes enn hva den er idag. Disse samlingene fremstår som bisarre og underlige for oss, på tross av at de er ganske så nær både i tid og i kulturelt rom. De fremstår som kaotiske, utenfor kontroll i sin hemningsløse tilbedelse av det merkverdige.

I boka "Die Kunst- und Wunderkammern der Spätrenaissance” (Schlosser 1908) finner vi en detaljert beskrivelse av mange av disse. Her kan vi f.eks. lese at det i utstillingen i Ambras fantes utstoppede kroko- 
diller, strutseegg, musikkautomater, en stump av repet Judas hengte seg i, gammelfrankiske våpen, og knokler av dverger og kjemper. I Hradschin var det tordensteiner og hieroglyfer, magneter og nagler "visstnok fra Noas ark", misfostre, heksekrutt, en perpeteeum mobile, elefantstøttenner, et kjøretøy som "falt fra himmelen ned i Hans Majestets leir da han var i Ungarn", spiritistiske hjelpemidler, og bezoarer - kalkavsetninger i magesekken til enkelte eksemplarer av en art persisk fjellgeit, virkningsfullt mot all slags forgiftning (etter Johansen 1990: 48 - 49). Tilsvarende fremmed for oss står Ole Worms "Museum Wormianum" i København fra 1600-tallet. I en seinere beskrivelse av denne heter det: "Mellom hjorte-takker, etnografiske gjenstande og utstoppede fugle, findes kopier av klassiske kunstverker, oldsaker ligger side om side med naturmerkverdigheter, misfostre og meget andet" (Bering-Liisberg 1897: 67).

Ved å presentere utsnitt av slike samlinger kunne vi vise at museet slik det fremstår idag, med sin disiplinerte kunnskap, er en ny måte å tenke på og å organisere verden på, ikke slikt alle mennesker alltid har tenkt. Det er faktisk radikalt forskjellig fra hvordan man tenkte bare for noen få hundre år siden her i vest. At prosessen med å fjerne tordenkilene fra kaoset i raritetskabinettene til å innsette dem som disiplinerte steinøkser på museum, representerer et radikalt brudd $\mathrm{i}$ verdensoppfatning. Man kunne vise at tilkomsten av det disiplinerte museet, ikke nødvendigvis bare representerte fornuftens endelige triumf, men at det også inngikk i sosiale og politiske praksiser med vidtrekkende konsekvenser. En av disse var distinksjonen mellom historiske folk og folk uten historie, mellom "Volkskunde" og "Völkerkunde", mellom svensk historie og samisk etnografi. Museene var mer enn en ideologisk refleksjon av denne distinksjonen, de var med på å skape den, gi den realitet og aksept i den vestlige bevissthet $\mathrm{i}$ form av distinksjonen mellom det historiske og det etnografiske museum. Ennå idag ser vi dette mange steder i Skandinavia. Den samiske kulturen er frosset i de etnografiske avdelinger, men de dynamiske norske, danske og svenske folk făr sin organiske utvikling presentert $\mathrm{i}$ de historiske museer (Schanche og Olsen 1985, Olsen 1986).

$\AA$ historisere fortida er samtidig å historisere nåtida, å lokalisere våre egne verdier, moral og fornuft i en kulturell og historisk kontekst. Vi må vise hvor eksotisk vår egen konstituering av virkeligheten har vært, historisere de domener som mest av alt er tatt for gitt som universelle. På dette vis blir museal formidling en form for kulturkritikk. $\AA$ oppdage at fortiden ikke tilsvarer våre normer og verdier, at den ikke lar seg forstå innenfor en ramme av instrumentell fornuft, kan være en god lekse å bli lært. Vi kan lære at vår egen nytte-oppfatning av verden ikke er en naturlig del av menneskeheten, men et kulturelt og historisk tilkommet fenomen. I ei tid da denne nytte-tenkningen gjennom et hensynsløst profittjag snart har lagt verden øde, og hvor det igjen synes å ha blitt et moralskt imperativ å påtvinge andre folkeslag vår kultur og styresett, kunne det kanskje være betimelig å minne om denne lokaliseringen.

Skal da museet bare være kritikk?. Nei, det skal det ikke og det er det da heller ingen overhengende fare for at det skal bli. Men det skal være det også. Innenfor museene, i utstillingsdebatten, må det finnes noe vi kanskje kunne sammenligne med en kritisk journalistikk. Denne finnes knapt nok 
58 i dag, ihvertfall ikke når det gjelder arkeologisk formidling. Vi trenger muldvarper som kan underminere noe av tatt-for-gitthetene, og selvforherligelsen $\mathrm{i}$ dagens museumsverden. Det er selvsagt ikke noe galt i å formidle den kunnskap man idag har om fortiden. Det både skal og bør man gjøre. Men man skal også formidle hvordan denne kunnskap fremkommer, hvilke konflikter den er involvert i, og hvordan den endres. Marinetti ønsket å rive museene. Det er kanskje å gå for langt. Men de må helt klart ristes litt $\mathrm{i}$.

\section{SUMMARY}

\section{The Archaeological Museums - Some Critical Points}

Archaeology's public identity is inextricably linked to museums and museum practice. The museum exhibitions constitute the main point of contact between archaeology and the public. In official scholarly and political discourse the social role of the museum is claimed to be that of the protection and conservation of prehistoric material and the presentation of knowledge about the past to the public. Furthermore, it is often maintained that the museum should provide a connection with history and a stability and thus impart to society a sense of its roots and its identity.

This paper argues against this sympathetic view of the museum's social role. Instead it is claimed that, to a considerable degree, the historical and archaeological museums serve to legitimise ideologically our modern, western way of life. The main argument is that most archaeological exhibitions eliminate what is particular and conditioned by the precise situation in time to both the past and the present. Focusing on well-known and easily recognisable categories such as technology, economy, settlement and religion, the historicity and difference of both the past and the present are erased. Both the bizarre in and the alternatives to our own way of life are concealed in this modern museum meta-narrative.
One of the reasons why archaeological exhibitions have become servants of current ideological interests, is that those who produce the exhibitions mainly regard their task as a question of communication. This emphasis on rhetoric, e $\mathrm{g}$ how to present the message in the most pedagogical and convincing way, has displaced any discussion of the crucial problem concerning the production of archaeological knowledge. Instead this rhetoric assumes an idyllic consensus about the past, that there exists a given portion of knowledge, and that the main problem consists in transferring this knowledge from the archaeologist to the public.

To alter this situation, a new museology has to focus on the problems involved in the production of knowledge. It has to visualise this production as an active process in a current socio-political context. There is no genuine and homogeneous past to be brought into harmony with archaeological thought and then neutrally re-presented to the public. Exhibitions should focus more on the plurality of interpretations and stimulate the interpretative creativity of the visitors. This also involves showing them how the interpretations of the past have changed through time and what they changed in response to. Finally, and maybe most important, a new presentation of the past has to emphasise the difference and otherness of the past. Doing this will enable us to place our own values, morality and reasoning, the universality of which we take for granted, in a cultural and historical context.

Bjornar Olsen, mag.art. i arkeologi, ansatt som arkeolog ved Tromso universitet. Arbeider med orientering mot et bredt spekter av sporsmal knyttet til arkeologiens teoretiske fundament. Var gjestende forskningsstipendiat $i$ Cambridge 1985-86 (Adr: Tromsø Museum, Ark. avd., Folkeparken, N-9000 Tromso). 


\section{LITTERATUR}

Adolfson, G. 1987. Människa och objekt i smyckeskrin. En analys av arkeologiska utstellningar i Sverige, Stockholm/Lund

Adorno, T. W. 1984. Prisms. The MIT Press, Cambridge, Mass.

Adorno, T. W. og M. Horkheimer 1979. Dialectic of Enlightenment, Verso, London

Barthes, R. 1973. Mythologies. Paladin Books, London

Barthes, R. 1977. Image-Music-Text, Fontana Books, London

Barthes, R. 1986. The rustle of language, Blackwell, Oxford

Bering-Liisberg, H. C. 1897. Kunstkammeret, dets stif telse og aldste historie, København

Bourdieu, P. 1984. Distictions: a social critique of the judgement of taste. Routhledge, London

Donato, E. 1979. The museum`s furnace, i: J. Harari (red.), Textual strategies, Ithaca

Ekeland, T. 1990. Arkeologi og formidling. En analyse av form og innhold i norske museers presentasjon av fortid. Hovedfags-oppgave i arkeologi, Universitetet i Bergen

Foucault, M. 1977. The Order of Things, Tavistock, London

Gjestrum, Aa. J. og M. Maure (red.) 1988. Økomuseumsboka - identitet, økologi, deltagelse. Norsk ICOM, Tromsø

Hansen, A. M. 1979. Øksen, i: A. M. Hansen, Volven og jomfruen og andre essays, Gyldendal, København

Held, D. 1980. Introduction to critical theory. Hutchinson, New York

Hodder, I. 1984. Archaeology in 1984. Antiquity 58: $25-32$

Hodder, I. 1990. Archaeology and the post-modern. Anthropology Today 6 (5): 13 - 15

Hodder, I. 1991. Interpretive archaeology and its role. American Antiquity 56 (1): 7 - 18

Johansen, A. 1989. Ting, tid, identitet. Syn og Segn, september 1989

Johansen, A. 1990. Museets modernitet - del I. Samtiden 6/1990: 40 - 49
Johansen, A. 1991. Museets modernitet - del II. Samtiden 1/1991: 56 - 64

Leone, M. 1981. The relationship between artefacts and the public in outdoor history museums. Annals of the New York Academy of Sciences 376: 301 - 14

Leone, M. 1982. Some opinions about recovering mind. American Antiquity 47: 742 - 759

Liestøl, G. 1988. Notat om museet som massemedium. Nicolay 50

Marinetti, F. T. 1965. The futurist manifesto, i: R. Ellman og C. Feildelson (red.) The modern tradition, New York

Merriman, N. 1989. Museum visiting as cultural phenomenon, i: P. Vergo (red.) The New Museology, Reaktion Books, London

Olsen, B. 1986. Norwegian archaeology and the people without (pre)history, or: how to create a myth of a uniform past. Archaeological Review from Cambridge 5(1)

Olsen, B. 1987. Arkeologi,tekst,sanfunn. Fragmenter til en post-prosessuell arkeologi. Stensilserie B, historie/arkeologi r. 24, ISV, Universitetet i Tromsø

Olsen, B. 1988. Det retoriske museum: en fortelling om makt og fortid. Nicolay 49

Olsen, B. 1990. Roland Barthes: From sign to text, i: C. Tilley (red.) Reading Material Culture, Blackwell, Oxford

Schanche, A. og B. Olsen 1985. Var de alle nord menn? En etno-politisk kritikk av norsk arkeologi, i J. R. Næss (red), Arkeologi og etnisitet, AmsVaria 15, Stavanger

Schlosser, J. von 1908. Die Kunst- und Wunderkammern der Spät-renaissance. Leipzig

Shanks, M. og C. Tilley. Re-constructing archaeology. Theory and practice. Cambridge University Press 